\title{
Zdôrazňovanie apoštolskej tradície v sporoch s heretikmi - Rím ako privilegované miesto tejto tradície
}

\author{
TEREZA REHORČÍKOVÁ
}

\section{Bratislava}

Focusing on apostolic tradition in the conflicts with the heretics - Rome as privileged place of this tradition

Abstract: The apostolic churches, as guarantors of orthodox doctrine, had generally higher authority than all other churches, because it was believed that the apostolic faith was certainly preserved in them. In the fight against gnosis in the second half of the $2^{\text {nd }}$ century, Christian authors argued with the apostolicity of the church and they used to use the Roman Church as the perfect and the most appropriate example precisely because of its exceptional apostolic origin. The first author and witness of this state is Hegesippus, whose argument - the preservation of true apostolic faith due to succession of bishops in every church where he used Rome as the best example - was deepened by Ireneus of Lyon. Rome has in his Adversus Haereses the "fullness" of apostolicity, is the most apostolic church of all churches thanks to its connection to both Peter and Paul and their martyrdoms. Therefore, every other church in which the apostolic faith and tradition is preserved must ipso facto agree with Rome. Moving forward Rome is the best example for demonstrating apostolicity of the whole church. The question for the last analysed author from this period - Tertullian - was how to discern from the heretic and apostolic reading of the Scripture since Gnostics used the same texts with completely different explanation. The answer was (to put the simplest) the apostolic faith itself. It is again passed through generations thanks to succession of bishops and the best places where to verify it are apostolic churches. Rome is not as obviously named as the best example; the fortresses of the true faith the apostolic churches were equal, still the Rome in his enumeration covers more place. It is the testimony of the very high reverence for Roman church, which was quite common during the whole Christian antiquity.

Keywords: apostolic tradition, church of Rome, Ireneus of Lyon, succession of bishops, papal primacy.

DOI: https://doi.org/10.24040/ahn.2021.24.01.05-18

Druhú polovicu 2. storočia poznačili boje s gnózou a cirkev proti nim používala apoštolskú tradíciu ako objektívnu smernicu viery. ${ }^{1} \mathrm{~V}$ boji

\footnotetext{
${ }^{1}$ Apoštolskú tradíciu (od trado, ere, = odovzdávat', podávat', prenechávat', postupovat', dedit', zverit', povedat', rozprávat', vykladat', vyučovat', prednášat') chápem ako učenie apoštolov, ktoré sa zachovalo neporušené doteraz (do doby vzniku konkrétnych diel, ako aj do
} 
s tradíciami gnostikov prístupnými len vyvoleným, ktoré boli tajné s nejasným historickým pozadím, a preto t’ažko historicky overitel'né, cirkevní spisovatelia zdôrazňovali, že apoštolská tradícia cirkvi je jedna a tá istá pre všetkých krest'anov (neexistujú VIP krest'ania s hlbším zasvätením do učenia), verejne známa, a teda overitel'ná a prístupná všetkým. Pre tých, ktorí by ju chceli spoznat', je to možné vd’aka Svätému písmu - práve preto je toto obdobie, kedy sa už z väčšej časti vyformoval dnešný kánon NZ (explicitným svedectvom je Muratoriho kánon $)^{2}$ a dáva sa do protikladu s apokryfnými spismi. Pravost' tejto všeobecne dostupnej tradície sa dá overit’ vd’aka biskupskému nástupníctvu, a preto začínajú vznikat' prvé zoznamy biskupov, aby sa doložilo, že cirkvi majú neporušenú biskupskú „líniu“ od apoštolov. ${ }^{3}$ Prvým svedectvom tohto stavu je Hegesippus.

Hegesippus (cca 110 - cca 180), rozrušený z toho, ako vel'mi sa rozšírila gnóza, sa vydal na okružnú cestu po cirkvách, a predovšetkým do Ríma, ${ }^{4}$ aby si overil, aké učenie bolo univerzálne prijímané vd'aka biskupskému nástupníctvu. Ciel' sa mu podarilo dosiahnut' 5 a ako dôkaz podáva (neúplný) zoznam rímskych biskupov: „Zahrnul som (doslova urobil pre seba) nástupníctvo až po Anicéta, ktorého diakonom bol Eleutherius; Sóter nastúpil po Anicétovi a po ňom Eleutherius. V každom nástupníctve a v každom meste sa týmto spôsobom zachovalo ohlasova-

našej súčasnosti). Porovnaj tiež Katechizmus Katolíckej cirkvi 76, 77, 78. Trnava : Spolok sv. Vojtecha, 2020, s. 30.

${ }^{2}$ Datovanie nie je isté, ale najčastejšie sa spomína ako obdobie jeho vzniku koniec 2 . a začiatok 3. storočia. HILL, Charles E.: The Debate Over the Muratorian Fragment and the Development of the Canon. In: Westminster Theological Journal. tom. 57, vol. 2, 1995, s. 437, 452. Dostupné online https://www.earlychurch.org.uk/pdf/fragment_hill.pdf [cit. 7. 5. 2020]. Taktiež HORKA, Róbert: Muratoriho zlomok: poznámky k textu a slovenský preklad. In: DISPUTATIONES SCIENTIFICAE UNIVERSITATIS CATHOLICAE IN RUŽOMBEROK, tom. 2, vol. 4, 2002, s. 52. Dostupné online https://www.academia.edu/10978023/Muratiorian_Fragment_ Adnotations_and_Slovak_translation_of_text [cit. 17. 4. 2021]. Autor uvádza aj slovenský preklad Muratoriho kánonu. Za upozornenie na túto štúdiu d’akujem recenzentke Mgr. et Mgr. Marcele Andokovej, MA, PhD.

${ }^{3}$ SCHATZ, Klaus: Dějiny papežského primátu. Brno : Centrum pro studium demokrace a kultury, 2002, s. $13-14$.

${ }^{4}$ Explicitne sa spomína v EUSEBIUS Z CÉZAREY, Historia Ecclestica (d’alej len HE), 4, 22 len Rím a Korint, pričom Rím je jeho konečná zastávka - ciel'. Tieto dve mestá sú uvedené s najväčšou pravdepodobnost'ou kvôli nepopieratel'nej apoštolskej tradícii. Hegesippus síce neuvádza apoštolov explicitne ako pôvod biskupského nástupníctva, zmienka o týchto mestách však implikuje, že to takto chápal. TWOMEY, Vincent: Apostolikos Thronos. The Primacy of Rome as reflected in the Church History of Eusebius and the historico-apologetic writings of Saint Athanasius the Great. Aschendorff : Münster, 1982, s. 25.

${ }^{5}$ EUSEBIUS: The History of the Church from Christ to Constantine. LOUTH, Andrew (ed.). London : Penguin Books, 1989, s. 129. HE, 4, 22, 1. „[...] ked' cestoval až do Ríma, nadviazal kontakt s množstvom biskupov a našiel rovnaké učenie u všetkých." 
nie Zákona, prorokov a Pána."6 Kl'účové je slovo oǔ $\omega \varsigma$ = týmto spôsobom, čím Hegesippus odkazuje na Rím - tak ako v Ríme (tým istým spôsobom ako v Ríme, čiže vd'aka overitel'nému biskupskému nástupníctvu, ktoré pre Rím aj stručne načrtol), sa pôvodné učenie udržiava vo všetkých cirkvách. Vyjadrené jednoduchšie - pravé apoštolské učenie sa uchováva biskupským nástupníctvom, pričom Rím uviedol ako konkrétny príklad. Biskupské nástupníctvo je garanciou, že učenie v danom časovom období je rovnaké, ako učenie predchádzajúcich generácií až po apoštolov. Zároveň prostredníctvom biskupského nástupníctva môže byt' splnená jedna zo základných podmienok pravosti apoštolského učenia - jeho priestorová rozšírenost' vo všetkých cirkvách. Hegesippov implicitný argument sa dá zhrnút' nasledovne: ak biskupi ${ }^{7}$ jednotlivých cirkví vd’aka biskupskému nástupníctvu odvodzujú svoju autoritu od toho istého a jediného prameňa - apoštolov - a tak uchovávajú pôvodné

${ }^{6}$ EUSEBIUS Z CÉZAREY, HE, 4, 22, 3. Preklad a zvýraznenia podl'a: TWOMEY, V.: Apostolikos Thronos, s. 23. Na s. 24 podáva aj prehl'ad interpretácií tohto textu od niekol'kých autorov. Twomey namieta proti prekladu EUSEBIUS: The Ecclesiastical History. LAKE, Kirsopp (prel.). 1. zv. London : William Heinemann; New York : G. P. Putnam's Sons, 1926, s. 375. Dostupné online https://archive.org/details/ecclesiasticalhi01euseuoft/page/n7/mode/ 2 up [cit. 26. 6. 2020]: „V každom zozname [biskupov] a v každom meste sa veci majú tak, ako to ohlasuje Zákon, proroci a Pán. "Podobný preklad podáva aj Williamson - prekladatel' vydania z poznámky č. 5 - EUSEBIUS: The History of the Church, s. 129: „V každej nástupníckej línii biskupov a v každom meste sú veci v súlade s ohlasovaním Zákona, prorokov a Pána." Argumentácia je rozsiahla, najpodstatnejšou námietkou je to, že takýto preklad je hodnotením Hegesippa (na spôsob inšpektora), že je vo všetkých cirkvách, ktoré navštívil, dodržiavané apoštolské učenie. Tým pádom by on sám zo seba robil poslednú autoritu, ktorá má rozhodovat' o tom, čo je alebo nie je apoštolským učením, či je alebo nie je uchované. Takýto postoj by stál v priamom rozpore s jeho úmyslom - íst' zistit' či overit' si, aké je autentická apoštolská náuka.

${ }^{7}$ V Hegesippovom chápaní biskupa je zdôraznená jeho učitel'ská autorita, neznamená to však, že nepripúšt'al iné funkcie či role prítomné v biskupskom úrade. Táto črta viedla $\mathrm{k}$ argumentom, že Hegesippus nezostavil zoznam biskupov, ale iba učitel'ov. Proti tomu VON CAMPENHAUSEN, Hans Freiherr: Kirchliches Amt und geistliche Vollmacht in den ersten drei Jahrhunderten. Tübingen : J. C. B. Mohr (P. Siebeck), 1953, s. 181 - 182. Podl'a: TWOMEY, V.: Apostolikos Thronos, s. 25. Apoštolská náuka v starovekej cirkvi nemôže byt' chápaná čisto ako „zoznam“ spísaných alebo tradovaných právd, ale predovšetkým ako prostriedky, ktorými sa veriaci aktívne zúčastňovali na živote cirkvi. V (liturgickom) živote cirkvi sa prejavovala jej náuka. Vrcholným bodom tohto života a jedným z hlavných prostriedkov účasti na apoštolskom učení a vyjadrením jednoty cirkvi bolo spoločné slávenie eucharistie. A tak biskup, ktorý predsedal eucharistickému sláveniu, bol najviac zodpovedný za pravú apoštolskú náuku a jej odovzdávanie, a teda vyučovanie, z čoho vyplývalo aj právo niekoho exkomunikovat'. TWOMEY, V.: Apostolikos Thronos, s. 25. Porovnaj: „Nech nikto nerobí nič, čo sa týka cirkvi, bez biskupa. [...] Nech sa za platne slávenú eucharistiu považuje tá, ktorú celebruje biskup alebo niekto, koho on poverí. [...] Ani nie je dovolené bez biskupa krstit' a konat' agapé [...]. “ IGNÁC Z ANTIOCHIE, Smyrn, 8, 1 - 2. In: JURGENS, William A. (ed.): The faith of the early Fathers. 1. zv. Collegeville : Liturgical Press, 1970, s. 25. Tiež IGNÁC Z ANTIOCHIE: Phld, 3, 2 - 3; 4, 1. In: JURGENS, W. A. (ed.): The faith of the early Fathers, 22. 
apoštolské učenie, potom to isté pravé apoštolské učenie musí byt' prítomné vo všetkých cirkvách. ${ }^{8}$

Hegesippov argument zachovávania pravej viery v dôsledku biskupského nástupníctva a jej následnej priestorovej rozšírenosti vo všetkých cirkvách, kde Rím uviedol ako konkrétny príklad, rozpracoval Irenej z Lyonu v diele Adversus Haereses (okolo 185, d’alej AH).

\begin{tabular}{|c|c|}
\hline $\begin{array}{l}\text { 1. Traditionem itaque } \\
\text { Apostolorum in toto mundo } \\
\text { manifestatam, in omni Ecclesia } \\
\text { adest perspicere omnibus qui vera } \\
\text { velint videre, et habemus } \\
\text { annumerare eos qui ab Apostolis } \\
\text { instituti sunt Episcopi in ecclesiis, } \\
\text { et successiones eorum usque ad } \\
\text { nos, qui nihil tale docuerunt, neque } \\
\text { cognoverunt, quale ab his deliratur. } \\
\text { Etenim si recondita mysteria scissent } \\
\text { Apostoli, quae seorsim et latenter ab } \\
\text { reliquis perfectos docebant, his vel } \\
\text { maxime traderent ea quibus etiam } \\
\text { ipsas ecclesias committebant. Valde } \\
\text { enim perfectos et irreprehensibiles in } \\
\text { omnibus eos volebant esse, quos et } \\
\text { successores relinquebant, suum } \\
\text { ipsorum locum magisterii tradentes: } \\
\text { quibus emendate agentibus fieret } \\
\text { magna utilitas, lapsis autem summa } \\
\text { calamitas. Sed quoniam valde } \\
\text { longum est, in hoc tali volumine } \\
\text { omnium ecclesiarum enumerare } \\
\text { successiones, maximae, et } \\
\text { antiquissimae, et omnibus } \\
\text { cognitae, a gloriosissimis duobus } \\
\text { Apostolis Petro et Paulo Romae } \\
\text { fundatae et constitutae ecclesiae, } \\
\text { eam quam habet ab Apostolis } \\
\text { traditionem, et annuntiatam } \\
\text { hominibus fidem, per successiones } \\
\text { Episcoporum pervenientem usque } \\
\text { ad nos indicantes, confundimus } \\
\text { omnes eos, qui quoquo modo vel per } \\
\text { sibiplacentiam malam, vel vanam } \\
\text { gloriam, vel per caecitatem et malam }\end{array}$ & $\begin{array}{l}\text { 1. Tradíciu apoštolov, ktorá je } \\
\text { známa na celom svete, je umož- } \\
\text { nené spoznat' v každej cirkvi } \\
\text { všetkým, ktorí by chceli vidiet' } \\
\text { pravdu. Máme za úlohu vymeno- } \\
\text { vat' tých, ktorí boli ustanovení } \\
\text { apoštolmi v cirkvách za biskupov } \\
\text { a ich nástupcov až do našich čias. } \\
\text { Oni nevyučovali ani nepoznali nič } \\
\text { také, o čom títo blúznia [gnostici, } \\
\text { proti ktorým Irenej píše]. Ved' } \\
\text { predsa, keby apoštoli boli poznali } \\
\text { skryté tajomstvá, ktorým by učili } \\
\text { dokonalých potajomky a oddelene } \\
\text { od ostatných, odovzdali by ich pre- } \\
\text { dovšetkým tým, ktorým zverili aj } \\
\text { samotné cirkvi. Ved' vel'mi chceli, } \\
\text { aby nástupcovia, ktorých zanechali } \\
\text { a ktorým odovzdali svoje miesto sa- } \\
\text { motných učitel'ov, boli dokonalí } \\
\text { a bezúhonní vo všetkom. Ak títo } \\
\text { bezchybne konajú, je to na vel'ký } \\
\text { osoh, ak pochybia, je z toho vel'ké } \\
\text { nešt'astie. Ale pretože by bolo } \\
\text { vel'mi zdíhavé v diele takéhoto } \\
\text { charakteru vymenovat' nástup- } \\
\text { níctva vo všetkých cirkvách, my } \\
\text { tu poukážeme na najvýznamnej- } \\
\text { šiu a najstaršiu, a všetkým } \\
\text { známu, založenú a ustanovenú } \\
\text { najslávnejšími apoštolmi Petrom } \\
\text { a Pavlom v Ríme, ktorá má tradí- } \\
\text { ciu od apoštolov a vieru, ktorá } \\
\text { bola ohlasovaná lud'om [apoš- } \\
\text { tolmi, čiže odvodenú od Krista], } \\
\text { a ktorá sa cez sled biskupov do- } \\
\text { stala až k nám. A tým zahanbujeme }\end{array}$ \\
\hline
\end{tabular}

8 TWOMEY, V.: Apostolikos Thronos, s. 24- 25. 
Zdôrazňovanie apoštolskej tradície v sporoch s heretikmi ...

sententiam, praeterquam oportet colligunt. Ad hanc enim ecclesiam propter potentiorem principalitatem necesse est omnem convenire Ecclesiam, hoc est, eos qui sunt undique fideles, in qua semper ab his, qui sunt undique, conservata est ea quae est ab Apostolis traditio. 2.

Fundantes igitur et instruentes beati Apostoli Ecclesiam, Lino episcopatum administrandae Ecclesiae tradiderunt. Huius Lini Paulus in his quae sunt ad Thimoteum epistolis meminit. Succedit autem ei Anacletus: post eum tertio loco ab Apostolis episcopatum sortitur Clemens, qui et vidit ipsos Apostolos, et contulit cum eis, et cum adhuc insonantem praedicationem Apostolorum et traditionem ante oculos haberet, non solus: adhuc enim multi supererant tunc $a b$ Apostolis docti. Sub hoc igitur Clemente, dissensione non modica inter eos qui Corinthi essent fratres facta, scripsit quae est Romae Ecclesia potentissimas literas Corinthiis, ad pacem eos congregans, et reparans fidem eorum, et annuntians quam in recenti ab Apostolis acceperat traditionem, annuntiantem unum Deum omnipotentem, factorem coeli et terrae, plasmatorem hominis, qui induxerit cataclysmum, et advocaverit Abraham, qui eduxerit populum de terra Aegypti, qui collocutus sit Moysi, qui legem disposuerit, et prophetas miserit, qui ignem praeparaverit diabolo et angelis eius. Hunc Patrem Dominini nostri Iesu Christi ab ecclesiis annuntiari, ex ipsa scriptura, qui velint discere possunt, et apostolicam Ecclesiae traditionem intelligere, cum sit vetustior epistola his qui nunc všetkých, ktorí akýmkol'vek spôsobom zo samol'úbosti alebo z márnivosti, alebo zo zaslepenosti, alebo zo zlomysel'nosti, nadmieru mudrujú. Ved' je nevyhnutné, aby každá cirkev, to jest veriaci zovšadial', v ktorej sa navždy tými, čo sú zovšadial', zachováva, čo učili apoštoli, súhlasila s touto cirkvou, kvôli [jej] výnimočnému pôvodu. 2. Ked' založili a určili pravidlá pre [rímsku] cirkev, svätí apoštoli [Peter a Pavol] ju odovzdali Línovi, aby ju spravoval. Tohto Lína Pavol spomína vo svojich listoch adresovaných Timotejovi. Po ňom nastúpil Anaklétus; ako tretí po apoštoloch dostal biskupstvo Klement, ktorý ešte samotných apoštolov videl a stretával sa s nimi. A hoci mal ešte $v$ živej pamäti kázanie a učenie apoštolov, nebol jediný ved' vtedy ešte žili mnohí, ktorých apoštoli učili. Za jeho pontifikátu, ked' povstal medzi bratmi v Korinte nemalý spor, napísala im rímska cirkev vel'mi dôležitý list, ktorý ich priviedol k pokoju, obnovil ich vieru a oboznámil ich s učením, ktoré nedávno prijala od apoštolov, zvestujúc im všemohúceho Boha, stvoritel'a neba i zeme, tvorcu človeka, ktorý zoslal potopu a povolal Abraháma, ktorý vyviedol l'ud z Egypta, ktorý sa rozprával s Mojžišom, ktorý ustanovil Zákon a poslal prorokov, ktorý pripravil oheň diablovi a jeho anjelom. Tohto Boha, ktorého cirkvi ohlasujú ako Otca nášho Pána Ježiša Krista, môžu, ktorí by chceli, zo samotného písma [tu sa myslí 1 Klem] poznat' a [tiež] porozumiet' apoštolskej tradícii cirkvi, pretože list je starší od tých, ktorí teraz nepravdivo učia a ohlasujú iného Boha, ktorý je nad Stvoritel'a - tvorcu všetkého, 


\begin{tabular}{|c|c|}
\hline $\begin{array}{l}\text { falso docent, et alterum Deum super } \\
\text { Demiurgum et factorem horum } \\
\text { omnium que sunt commentiuntur. } 3 \text {. } \\
\text { Huic autem Clementi succedit } \\
\text { Euaristus, et Euaristo Alexander, ac } \\
\text { deinceps sextus ab Apostolis } \\
\text { constitutus est Sixtus, et ab hoc } \\
\text { Telesphorus, qui etiam gloriosissime } \\
\text { martyrium fecit: ac deinceps Hyginus, } \\
\text { post Pius, post quem Anicetus. Cum } \\
\text { autem successisset Aniceto Soter, } \\
\text { nunc duodecimo loco Episcopatum ab } \\
\text { Apostolis habet Eleutherius. Hac } \\
\text { ordinatione et successione ea quae } \\
\text { est ab Apostolis in Ecclesia traditio } \\
\text { et veritatis praeconatio pervenit } \\
\text { usque ad nos. Et est plenissima } \\
\text { haec ostensio, unam et eandem } \\
\text { vivificatricem fidem esse, quae in } \\
\text { Ecclesia ab Apostolis usque nunc } \\
\text { sit conservata, et tradita in } \\
\text { veritate. } 9\end{array}$ & $\begin{array}{l}\text { čo je. } 10 \text {. Po tomto Klementovi na- } \\
\text { stúpil Evaristus a po Evaristovi Ale- } \\
\text { xander, a potom, ako šiesty od } \\
\text { apoštolov, bol ustanovený Sixtus } \\
\text { a po ňom Telesfor, ktorý je slávnym } \\
\text { mučeníkom; a potom Hyginus, po- } \\
\text { tom Pius, po ktorom Anicetus. Pre- } \\
\text { tože po Anicetovi nastúpil Soter, te- } \\
\text { raz je ako dvanásty po apoštoloch } \\
\text { biskupom Eleutherius. Týmto po- } \\
\text { radím a postupnost'ou sa v [celej] } \\
\text { cirkvi učenie apoštolov a hlása- } \\
\text { nie pravdy dostalo až k nám. A } \\
\text { toto je úplný dôkaz, že je jedna } \\
\text { a tá istá oživujúca viera, ktorá sa } \\
\text { v cirkvi zachovala od apoštolov } \\
\text { a odovzdávala sa v pravde až do- } \\
\text { teraz. }\end{array}$ \\
\hline
\end{tabular}

Podl'a Ireneja sa apoštolská tradícia cirkvi dá spoznat’ v každej miestnej cirkvi, pretože si je istý, že v každej by sa dal urobit' zoznam biskupov, ktorý začína pri niektorom z apoštolov. Ked'že dokazovat' toto tvrdenie by bolo príliš zdíhavé (ak aj nie nemožné), stačí poukázat' na Rím, ktorý je všeobecne známy a výnimočného pôvodu, a podáva teda zoznam rímskych biskupov.

Aby sa dalo jasnejšie pochopit', o čo ide, niektoré kl'účové frázy sú analyzované podrobnejšie. Ešte predtým je potrebné upozornit' na dve veci: pre pasáž 3, 3,1 nemáme grécky originál, čo st’ažuje situáciu. Na základe porovnania iných pasáží, kde sa naopak pôvodný grécky text

\footnotetext{
${ }^{9}$ IRENEJ Z LYONU: Adversus haereses. W. W. HARVEY (ed.). 2 zv. Cantabrigiae : Typis Academicis, 1857, s. 8 - 12. AH 3, 3, 1 - 3. Dostupné online: https://archive.org/details/ sanctiirenaeiep00harvgoog/page/n2/mode/2up. [cit. 27. 4. 2020]. Za pomoc pri prekladoch z latinčiny d'akujem svojmu školitel’ovi diplomovej práce doc. Mgr. Imrichovi Nagyovi, PhD.

${ }^{10}$ Boh SZ = Stvoritel' = Demiurg bol v gnostickom chápaní iba nedokonalá, nižšia, neúplná, hlúpa až démonická a zvrátená bytost', ktorá nepozná pravého Najvyššieho Boha a nemá s ním nič spoločné, hoci vzišiel z eónov (konkrétne z posledného eóna Sofie) - nebeských bytostí emanujúcich z tohto Najvyššieho Boha. Demiurg svoj božský pôvod nepozná. Gnostici utrpenie vo svete a nedokonalost' človeka vysvetl'ovali tým, že ich tvorcom bol práve Demiurg, ktorý si v momente stvorenia materiálneho sveta ani neuvedomoval, že ich tvorí ako napodobeninu sveta božského. Je vládcom priestoru a času, nie je však všemohúcim Bohom. PINKAS, Matej: Charakteristické znaky starovekej gnózy a gnosticizmu. In: Acta Facultatis theologicae Universitatis Comenianae Bratislaviensis, tom. 14, vol. 2, 2017, s. 49 - 52.
} 
zachoval, sa však potvrdilo, že latinský preklad je skoro doslovný. ${ }^{11}$ Po druhé interpretácia tejto pasáže je už desat'ročia nevyriešeným problémom a žiadna z mnohých možných interpretácií12 nie je všeobecne prijímaná. Samozrejme, sú medzi nimi „hlavné“, ktoré majú viac zástancov a „boj“ sa odohráva predovšetkým medzi nimi, iné sa dajú odmietnut' celkom jednoducho.

Prvá čast', kde Irenej hovorí o rímskej cirkvi, je svojím vzletným a oslavným jazykom charakterovo blízka starším prameňom. Táto úcta sa prejavuje napríklad v listoch Ignáca z Antiochie, liste Dionýzovi z Korintu rímskemu biskupovi Soterovi a v rozšírenosti a autorite, akej sa tešil 1. Klementov list napísaný rímskou cirkvou do Korintu. Rímska cirkev v týchto prameňoch nikdy nie je karhaná či napomínaná, vždy je s ňou spätý jazyk plný chvály, miestami až poetický a oslavný. Iné cirkvi, v tom aj najstaršie a apoštolské, sú objektom výčitiek či napomenutia a nikdy sa netešili porovnatel'nej úcte ako cirkev v Ríme. ${ }^{13}$ Ked' Irenej spomína Petra a Pavla ako zakladatel'ov rímskej cirkvi, nie je jasné, či to naozaj pokladal za historický fakt, alebo ide o rétoriku, ktorou sa vyjadruje všeobecne prijímaná pevná previazanost' rímskej cirkvi s týmito dvoma apoštolmi. Pravdepodobne druhá možnost', pretože z Irenejovho pohl'adu na toto tesné puto nie je nevyhnutné, aby Peter a Pavol boli zakladatel'mi cirkvi a úplne prvými hlásatel'mi evanjelia v nej. ${ }^{14}$ Vo svojom preklade som sa rozhodla prívlastky maximae, et antiquissimae prekladat' superlatívmi, aby som zdôraznila úctu, ktorej sa rímska cirkev tešila. Avšak určite nejde o doslovný zmysel. Rímska cirkev nebola najväčšia v tomto období stále ešte ležala na okraji krest'anského sveta a značnejší počet veriacich dosiahla až v priebehu 3. storočia. ${ }^{15}$ Preto som zvolila výraz najvýznamnejšia, to však treba chápat’ v zmysle úcty, akej sa tešila, nie primátu. Nebola ani historicky najstaršia, čo si Irenej určite uvedomoval. Vo svetle pasáže 3, 4, 1,16 kde antiquissimae ecclesiae

\footnotetext{
${ }^{11}$ McCUE, James, F.: The Roman Primacy in the Second Century and the Problem of the Development of Dogma. In: Theological Studies, tom. 25, vol. 2, 1964, s. 176. Dostupné online http://cdn.theologicalstudies.net/25/25.2/25.2.1.pdf [cit. 10. 5. 2020].

12 Na začiatku 20. storočia Xavier Roiron vypočítal, že teoreticky je možné interpretovat' pasáž 3, 3, 1 na 108 spôsobov. ROIRON, X.: Sur l'interprétation d'un passage de saint Irénée: 'Adversus Haereses', III, 3, 1. In: Recherches de science réligieuse, tom. 7, vol. 1 - 2, 1917, s. 38. Podl'a: O’BOYLE, Michael: St. Irenaeus and the See of Rome. In: The Catholic Historical Review, tom. 16, vol. 4, 1931, s. 415.

13 SCHATZ, K.: Dějiny papežského primátu, s. 10 - 13.

${ }^{14}$ McCUE, J. F.: The Roman primacy, s. 179.

15 SCHATZ, K.: Dějiny papežského primátu, s. 25.

16 „Et si de aliqua modica quaestione disceptatio esset, nonne oporteret in antiquissimas recurrere ecclesias, in quibus Apostoli conversati sunt, et ab eis de praesenti quaestione sumere quod certum et re liquidum est?" [ = A keby aj v nejakej bežnej, každodennej záležitosti vznikol
} 
vyjadruje všeobecne chronologicky najstaršie cirkvi založené apoštolmi, ide teda o to, že Rím patrí medzi ne. V tomto zmysle možno prívlastky maximae, et antiquissimae preložit' v podobe vel'mi významnej a vel'mi starej. Použitie tohto prekladu by bolo vhodnejším zase $\mathrm{z}$ toho dôvodu, aby uchránilo čitatel’a pred zjednodušením, že Irenej uznával rímsky primát vo význame, ktorý sa blíži jeho modernému chápaniu (rímska cirkev je právne nadradená nad iné a/alebo rímsky biskup má právo robit' doktrinálne rozhodnutia, ktoré musia akceptovat’ všetky cirkvi).

Kvôli nasledujúcej analýze a problémom, ktoré vyvoláva preklad najdôležitejšej vety, dovolím si uviest' jej štylisticky neupravený preklad:

\begin{tabular}{|l|l|}
\hline 1 Ad hanc enim ecclesiam propter & Ved's touto cirkvou kvôli jej \\
2 potentiorem principalitatem & výnimočnému pôvodu \\
3 necesse est omnem convenire & je nevyhnutné, aby súhlasila každá \\
Ecclesiam, & cirkev, \\
4 hoc est, eos qui sunt undique & to jest tí, ktorí sú zovšadial' veriaci, \\
fideles, & v ktorej sa ustavične tými, čo sú \\
5 in qua semper ab his, qui sunt & zovšadial', \\
undique, & zachováva to, čo je tradíciou od \\
6 conservata est ea quae est ab & apoštolov [čo učili apoštoli]. \\
Apostolis traditio. & \\
\hline
\end{tabular}

Ked'že k tejto pasáži chýba originál, dost' pozornosti sa venovalo tomu, aké grécke slovo bolo preložené ako principalitas. Najviac sedí do kontextu arché vo význame začiatok, pôvod, základ. ${ }^{17}$ Pre Irenejovu generáciu krest'anov bola smerodajná ako autorita, ktorej je podriadený výklad Písma a disciplína, samotná viera a tradícia prijatá od apoštolov - preto robili zoznamy biskupov a zdôrazňovali apoštolský pôvod cirkví, aby sa nevyvrátitel'ne dokázalo, že táto viera je rovnaká, ako hlásal Kristus a akú učili apoštoli. ${ }^{18}$ Pre Ireneja má automaticky každá apoštolská cirkev vd'aka svojmu pôvodu pravú vieru. ${ }^{19}$ Ale Rím má vo svojom pôvode (resp. základe) prvenstvo či náskok (preto potentior) oproti iným cirkvám - má možnost' sa odvolat' na svedectvo mučeníckej smrti a hroby

\footnotetext{
spor, nemalo by sa azda obrátit' k najstarším cirkvám, v ktorých apoštoli pôsobili a od nich o tejto otázke zobrat' to, čo je isté a jasné?] IRENEJ Z LYONU: Adversus haereses, 3, 4, 1. s. 15-16. 17 McCUE, J. F.: The Roman primacy, s. 177. PIETRAS, Henryk: Świadomość prymatu biskupa Rzymu w kościele starożytnym. In: Kapłaństwo i urząd. Zost. W. Gajewski, Gdańsk: Wydawnictwo Uniwersytetu Gdańskiego, 2009, s. 190 - 205. TWOMEY, V.: Apostolikos Thronos, s. 92.

18 Toto bude najzretel'nejšie u Tertuliána. Pozri s. 11 - 12 .

${ }^{19}$ McCUE, J. F.: The Roman primacy, s. 178.
} 
dvoch významných apoštolov, pričom Peter bol vodcom Dvanástich. ${ }^{20} P o-$ tentior principalitas teda odkazuje na gloriosissimis duobus Apostolis Petro et Paulo a je dôvodom, ${ }^{21}$ prečo stačí dokázat' apoštolský pôvod (a následne biskupské nástupníctvo od apoštolov) Ríma, aby sa dokázalo, že celá cirkev je apoštolská. Všetky apoštolské cirkvi majú to, čo Rím - verejné hlásanie evanjelia a odovzdávanie apoštolskej tradície vd'aka biskupskému nástupníctvu siahajúcemu až k apoštolom, ale rímska cirkev je najlepším príkladom, pretože je to v nej prítomné „najplnším“, najviditel'nejším, najistejším a najjednoduchšie overitel'ným spôsobom. ${ }^{22}$ Nie je vhodné vidiet' za potentior principalitas uznanie práva rímskeho biskupa (či cirkvi) vydávat' doktrinálne rozhodnutia, s ktorými musia všetky ostatné cirkvi súhlasit'. Irenej v spomínanom úryvku 3, 4, 1 hovorí, že v prípade sporu sa treba obrátit' na akúkol'vek apoštolskú cirkev, nemusí to byt' nevyhnutne Rím vd’aka konfrontácii s inými prameňmi aj mimo AH (Tertulián, Cyprián z Kartága) je to naozaj pôvod rímskej cirkvi, čo z nej robilo privilegované miesto tradície (ako to výstižne sformuloval Schatz). ${ }^{23}$ Keby potentior principalitas označovalo vieroučnú autoritu rímskeho biskupa (či cirkvi), toto svedectvo by bolo bielou vranou, ked'že prax 2. aj 3. storočia ukazuje, že rozhodnutia rímskeho biskupa neboli vzhl'adom na všeobecnú cirkev akceptované (ak je vôbec vhodné použit' takúto formuláciu, pretože už čiastočne prenáša modernú skúsenost' do mentality a právneho fungovania cirkvi v danom historickom období). ${ }^{24}$

Ako vidiet' aj zo slovenského prekladu (riadok 5), jedným z najdôležitejších problémov pre celé generácie filológov, historikov či teológov je otázka, na čo sa vzt'ahuje in qua: či na rímsku cirkev, alebo na každú cirkev.

Pri prvej možnosti je $a b$ his qui sunt undique skoro neriešitel'nou prekážkou. Prečo by mali veriaci zovšadial' (z každej jednej cirkvi, čo je z praktického hl'adiska nezmyselné) udržiavat' v Ríme apoštolskú tradíciu? To priamo odporuje Irenejovmu chápaniu odovzdávania a zachovávania tejto tradície, čo sa dialo pomocou biskupského nástupníctva, ktoré ná-

\footnotetext{
20 Čo sa týka Petra, v podstate panuje zhoda (medzi katolíckymi a nekatolíckymi exegétmi), že bol ustanovený Ježišom Kristom ako hlava apoštolov (a teda Kristus mu na spravovanie cirkvi na zemi prepožičal svoju autoritu), čo sa vyvodzuje nielen z typických petrovských textov (Mt 16, 13 - 19; Lk 22, 31 - 32; Jn, 21, 15 - 17), ale aj z iných (napríklad Mt 4, 18; Mk 1, 16; Lk 5, 1 - 11; Jn 1, 35 - 42; Lk 6, 12 - 13; Mt 10, 2; Mk 3, 16 a d'alšie). SCHATZ, K.: Dějiny papežského primátu, s. 8.

${ }^{21} \mathrm{~V}$ súvislosti ešte s chápaním in qua ako odkazom na omnem ecclesiam, čomu sa venujem v nasledujúcich odsekoch, tento dôvod získava na úplnosti.

22 McCUE, J. F.: The Roman primacy, s. 178.

${ }^{23}$ SCHATZ, K.: Dějiny papežského primátu, s. 13.

24 Vzhl'adom na obsiahlost' problému predstavuje stručný prehl'ad REHORČÍKOVÁ, Tereza: Zdôvodnenie primátu rímskeho biskupa v ranokrest’anských prameňoch. Diplomová práca. Banská Bystrica, 2020 s. 13 - 19, 49 - 69. Dostupné online https://opac.crzp.sk/ ?fn=detailBiblioForm\&sid=780C5DA7522A72A29DF6FCDFDA41 [cit. 03. 02. 2020].
} 
sledne v 3, 3, 2 - 3 pre Rím podáva. ${ }^{25}$ Boli snahy prekladat' in qua inštrumentálom, čo však pravidlá gramatiky (latinskej aj gréckej) vylučujú. ${ }^{26}$ Niekol'ko teórii práve kvôli neustálym problémom spochybnilo pravost' $a b$ his qui sunt undique. ${ }^{27}$ Žiadna $\mathrm{z}$ nich nezískala všeobecné uznanie a nepodarilo sa ju definitívne potvrdit'. Hoci niektoré sú celkom pravdepodobné, nie sme nútení pristúpit' k takému riešeniu, kde sa ab his qui sunt undique považuje za chybu. Ako už bolo spomenuté, latinský preklad AH je dost' presný a veta bude dávat' zmysel pri opačnom tvrdení, ked' sa in qua vzt'ahuje na omnem ecclesiam.

V tomto prípade však treba vysvetlit' tautológiu a tiež problémom zostáva, čo znamená (rovnako ako v prípade vzt’ahovania in qua na Rím), že v každej cirkvi sa tými (veriacimi či cirkvami) zovšadial' zachováva apoštolská tradícia. ${ }^{28}$ Ale prikláňam sa k názoru, že je prirodzenejšie vzt'ahovat' in qua na omnem ecclesiam, pretože nasleduje hned' po hoc est eos qui sunt undique fideles a udržuje sa tým aktuálna myšlienka. Námietkou zo strany odborníkov zastávajúcich „pro-rímsku“ interpretáciu je, že celej vete (aj predchádzajúcej) dominuje rímska cirkev. ${ }^{29}$ Nie je to však nevyvrátitel'né - ak sa in qua vztiahne na omnem ecclesiam, ukáže sa, že táto čast' je vypracovaná podl'a štylistického pravidla inclusio, ktorú Irenej uplatňuje aj na iných miestach. ${ }^{30}$ Pasáž, kde sa spomína Rím, otvára tvrdenie, že je zdíhavé omnium ecclesiarum enumerare successiones, a uzatvára ju vyhlásenie, že s rímskou cirkvou pre jej výnimočný pôvod musí súhlasit' omnem ecclesiam. Čo sa týka druhej námietky, ide o úmyselné zopakovanie qui sunt undique fideles práve preto, aby sa predišlo

\footnotetext{
25 O’BOYLE, M.: St. Irenaeus and the See of Rome, s. 428 - 429. Táto interpretácia (veriaci zovšadial' zachovávajú vieru v Ríme) súvisí s prekladom convenire ad ako zhromažd'ovat' sa, schádzat' sa, čo O’Boyle vyvracia, s. 416 - 420.

${ }^{26}$ ABRAMOWSKI, Luise: Irenaeus, "Adv. Haer." III, 3, 2: Ecclesia Romana and omnis Ecclesia; and Ibid. 3, 3: Anacletus of Rome. In: The Journal of Theological Studies, tom. 28, vol. 1, 1977, s. 102. Abramowski vlastne reaguje na francúzsky preklad AH v edícii Sources chrétiennes, kde A. Rousseau vzt'ahoval in qua na rímsku cirkev.

${ }^{27}$ D’Herbignyho je najkomplikovanejšia a predpokladá sériu chýb (pisárskych, čo sa týka gréckeho textu, potom prekladatel'ských a nakoniec opät' pisárskych v latinskom texte). Saltet navrhol, že pôvodne tam nemalo byt' ab, ale iba datív his qui sunt undique, pričom chybu pripisuje pisárom. Podobnú teóriu zastáva aj Rousseau - chyba nastala nesprávnym prekladom datívu toĩc. Podl'a Morinovej teórie (najstaršia z uvedených, prvýkrát publikovaná v roku 1908) sunt undique je pisárska chyba, ked' pisár mimovol'ne zopakoval slová z predchádzajúceho riadka. O’BOYLE, M.: St. Irenaeus and the See of Rome, s. 430 - 432. On rozvíja d'alej Morinovu teóriu. ABRAMOWSKI, L.: Irenaeus, s. 102.

${ }^{28}$ O'BOYLE, M.: St. Irenaeus and the See of Rome, s. 426, 428.

${ }^{29}$ ABRAMOWSKI, L.: Irenaeus, s. 102 - 103. O'BOYLE, M.: St. Irenaeus and the See of Rome, s. 425.

${ }^{30}$ ABRAMOWSKI, L.: Irenaeus, s. 103. Rousseau uznáva, že Irenej využíva inclusio na iných miestach, ale nie tu.
} 
neporozumeniu, na čo sa vzt'ahuje in qua. ${ }^{31} \mathrm{Nie}$ je to úplne uspokojivé vysvetlenie, avšak vd'aka nemu sa dajú obíst' niekedy až krkolomné riešenia a nelogickost' tejto vety, ktorej sa nedá vyhnút', keby sa in qua vzt'ahovalo na rímsku cirkev. Navyše, ak in qua odkazuje na omnem ecclesiam, krásne to zapadá do kontextu Irenejovho argumentu, ako aj mentality jeho doby. Irenej explicitne skonštatoval, že rímska cirkev má tradíciu od apoštolov o vetu vyššie. Upozornil na to pri dokazovaní zachovávania apoštolskej tradície v cirkvi. Vkladat' to aj do tejto vety by rozbilo plynulú argumentáciu úryvku a práve to by bolo zbytočnou tautológiou. Význam je teda nasledujúci: každá cirkev, čiže veriaci zovšadial', v ktorej sa uchováva [bola zachovaná] apoštolská tradícia, musí súhlasit' s rímskou cirkvou pre jej výnimočný pôvod. Fakt, že každá cirkev zachovávajúca apoštolskú tradíciu nevyhnutne musí súhlasit’ s Rímom, lebo ten má apoštolský pôvod par excellence, nie je len triviálnym tvrdením. Týmto Irenej vytvoril súvislost' medzi rímskou cirkvou a každou d'alšou, ktorá má tiež apoštolskú tradíciu, čím buduje svoj argument, prečo stačí poukázat' na rímsku, aby sa dokázala apoštolskost' celej cirkvi.

Na základe uvedenej analýzy sa dá zhrnút', že rímska cirkev má „najapoštolskejší" pôvod zo všetkých apoštolských cirkví. Potentior principalitas je dôvodom, prečo si Irenej vybral práve rímsku cirkev ako najvhodnejší príklad. Pre „plnost'“ apoštolského pôvodu rímskej cirkvi, každá cirkev s biskupským nástupníctvom siahajúcim k apoštolom, ktorým sa uchováva pravá apoštolská viera, musí s ňou nevyhnutne súhlasit'. Tým Irenej dokazuje, že stačí uviest’ zoznam rímskych biskupov, aby dokázal apoštolskost' celej cirkvi: „Et est plenissima haec ostensio.“

K zoznamom rímskych biskupov je potrebné uviest', že začali vznikat' storočie po smrti Petra a Pavla v momente, kedy už bol monoepiskopát ${ }^{32} \mathrm{v}$ cirkvi etablovaný a rozšírený. Rozdiely v nich ${ }^{33}$ prezrádzajú, že vznikali na základe rôznych tradícií (písomných či ústnych). Ide o anachronické konštrukty, ktoré prenášali monoepiskopát do skorších foriem cirkevnej organizácie a zjednodušili koncept odovzdávania apoštolskej tradície na odovzdávanie biskupského úradu z jedného monobiskupa na druhého. ${ }^{34}$

\footnotetext{
${ }^{31}$ ABRAMOWSKI, L.: Irenaeus, s. 102.

${ }^{32}$ Monoepiskopát, čiže štruktúra jeden biskup - presbyteri - diakoni oproti dvojúrovňovému episkopátu presbyteri - diakoni. Pre stručný prehl'ad k problematike vývoja monoepiskopátu všeobecne a aj v Ríme REHORČÍKOVÁ, T.: Zdôvodnenie primátu, s. 27 - 29.

33 Rôzne poradie biskupov, niektoré uvádzajú chronologické dáta, niektoré nie, v datovaní pontifikátov sú značné rozdiely.

${ }^{34}$ STRAND, Kenneth A.: First-century Church organization in Rome. In: Andrews University Seminary Studies, tom. 29, vol. 2, 1991, s. 144 - 145. Dostupné online https://digitalcommons.andrews.edu/cgi/viewcontent.cgi?article=1990\&context=auss [cit. 19. 5.2020].
} 
Máme zachované tri hlavné tradície zoznamov rímskych biskupov: 1 . najstarší Irenejov, potom Eusebiov (HE aj Kronika, prelom 3. a 4. storočia) a Epifániov (Panarion 27, 6, okolo 375), 2. zoznam Optata z Milevis (cca 370) a Augustína (400), 3. tzv. rímsky zoznam v Liberiánskom katalógu (vypracovaný v polovici 4. storočia, hoci zoznam môže byt' starší), ktorý sa stal súčast'ou Liber Pontificalis. Hlavným sporným bodom je umiestnenie biskupa Klementa a) ako tretieho po Petrovi a Pavlovi, b) druhého po Petrovi, c) prvého po Petrovi (v tom istom poradí ako som uviedla tradície zoznamov). ${ }^{35}$

Hegesippov neúplný zoznam rímskych biskupov využil ako svoj zdroj určite Eusebius a pravdepodobne aj Irenej a Epifánius. ${ }^{36}$

Irenej dodal Lína a Anakléta, aby počet rímskych biskupov až do jeho súčasnosti bol správne apoštolský - dvanást'. Linus bol spolupracovní-

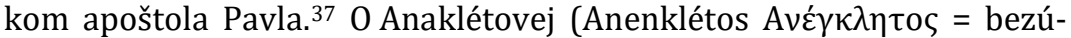
honný/bez pochybení, niet mu čo vyčítat') činnosti sa nedalo povedat' nič určitejšie, pretože jeho pôvod bol pravdepodobne iba literárny: $\delta \varepsilon \tilde{\imath} \gamma \alpha \grave{\alpha} \rho$

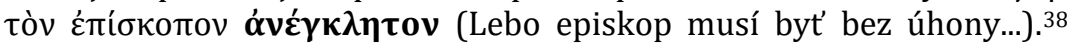
Každopádne, jedného aj druhého Irenej spájal s Pavlom, čím ešte upevnil previazanost' rímskej cirkvi s jej apoštolskými „zakladatel'mi“, a teda jej potentior principalitas. ${ }^{39}$ Týmto, a zároveň začiatkom svojho zoznamu od Petra a Pavla v kontraste s neskoršími tradíciami, kde sa zoznamy začínajú iba Petrom, Irenej prezrádza, že jeho záujem tkvie v pôvode rímskej cirkvi a chce jej dodat' čo najviac prepojení s apoštolmi. Jeho primárny záujem nezahŕňal autoritu biskupov Ríma ako takú (ich právomoci) ani sa nezaujímal výhradne o Petra a odvodzovanie autority biskupa Ríma od neho. Svojím zoznamom rímskych biskupov opät' potvrdzuje, že Rím je miestom privilegovanej tradície, ale je to vd'aka úzkemu a jedinečnému previazaniu s oboma apoštolmi. „Skutočne, nezlý príklad historickej genealogickej rekonštrukcie: pokial' ide o autoritu a spol'ahlivost' prameňov nepochybne, avšak nie vel'mi spol'ahlivý čo do svojich výsledkov. "40

\footnotetext{
Netvrdím tým, že to robili vedome - poznajúc dôkladne pôvodnú situáciu cirkevnej organizácie $\mathrm{v}$ apoštolských časoch sa rozhodli klamat' pre zvýšenie efektivity svojich argumentov. Rovnako toto anachronické prenesenie monoepiskopátu do 1 . storočia a fakt, že niektorí prví rímski biskupi sú vymyslené postavy (napr. Anaklétus), neznamená popretie apoštolskosti cirkvi (teda neprerušené odovzdávanie apoštolského učenia a svätenia presbyterov/biskupov z generácie na generáciu). To však je už otázka teologická.

${ }_{35}$ STRAND, K. A.: First-century Church organization in Rome, s. 145 - 146, 148, 150. Rímsky zoznam síce umiestňuje Klementa ako druhého po Línovi, avšak datovanie Línovho pontifikátu sa prekrýva s Petrovým životom, takže Klement je prakticky druhý po nich oboch.

${ }^{36}$ STRAND, K. A.: First-century Church organization in Rome, s. $146-147$.

372 Tim 4, 21; Tít 1, 7.

38 Tít 1,7

${ }^{39}$ ABRAMOWSKI, L.: Irenaeus, s. 104. Navyše Sixtus je podozrivo šiesty po apoštoloch.

${ }^{40}$ ABRAMOWSKI, L.: Irenaeus, s. 104.
} 
Posledným výrazným svedkom, ktorý bojoval apoštolskou tradíciou proti heretikom a je predmetom tejto štúdie, je Tertulián. Bol si vedomý, že Sväté písmo podlieha interpretácii - a heretici ho bez váhania používali na to, aby ním doložili svoje tvrdenia.

Autoritou, pomocou ktorej sa rozlišuje správna a heretická interpretácia, je pre Tertuliána regula fidei (viera samotná): Kristovo učenie jednoduché, jednotné, jasne a navždy určené, úplne a celé odovzdané apoštolom a od nich neporušene zverené cirkvám, ktoré založili. Nie je to ani autorita rímskeho biskupa, ani biskupov všeobecne či synod. Tie všetky sú podriadené regula fidei - nie sú jej pánmi, ale sluhami, netvoria ju, ale svedčia o nej a odovzdávajú ju. Episkopát je podriadený učeniu, ktoré dostal od predchádzajúcich generácií. Apoštolské cirkvi sú dôkazom, že doktrína sa odovzdáva neporušená d'alej. Ide však o dôkaz historický, nie odvolanie sa na ich autoritu ako takú - vd'aka nástupníctvu biskupov sa apoštolská viera podáva neporušená d’alej v celej cirkvi, ale najlepšie je to viditel'né a overitel'né v apoštolských cirkvách, preto sú svojím spôsobom špeciálne oproti „menším“ či sekundárne zakladaným cirkvám. Rím tu má výnimočné postavenie vzhl'adom na svoj pôvod - môže sa spájat' až s tromi apoštolmi, pričom Peter bol vodcom apoštolov a aj Ján mal medzi Dvanástimi výrazné a významné postavenie: 41 „Nyní, když chceš být přesněji obeznámen ve věci své spásy, projdi apoštolské církve, v nichž ještě stojí učitelské stolce apoštolů, v níchž se čtou pravé dopisy... Máš-li to nejblíže do Achaie, pak je to Korint. Pokud jsi nedaleko Makedonie, máš Filippoi. Jsi-li z Asie, máš Efesos. Jsi-li z oblasti Itálie, máš Řím, pod jehož autoritu spadáme i my [Afrika]. To je ta št'astná církev, které apoštolové spolu se svou krví dali celé učení, kde Petr svým utrpením napodobil Pána, kde Pavel byl korunován tím, že skončil jako Jan [Krstitel'], kde byl apoštol Jan ponořen do vroucího oleje, zůstal bez úhony, načež byl vyhnán na ostrov. “42 Ide o vel'mi podobný argument, ako u Ireneja v pasáži 3, 4, 1 z AH. Ale tiež, podobne ako Irenej v AH 3, 3, 1 - 3, Rím si „zaslúžil“ najviac miesta a oslavný jazyk. V uvedenom úryvku sa prejavuje aj „prvý vývojový stupeň “v otázke primátu rímskeho biskupa, a síce vel'ká úcta, ktorej sa rímska cirkev tešila naprieč celým impériom. ${ }^{43}$ Zo samotného faktu Petrovej

\footnotetext{
${ }^{41}$ ENO, Robert B.: Ecclesia docens : Structures of Doctrinal Authority in Tertullian and Vincent. In: The Thomist: A Speculative Quarterly Review, tom. 40, vol. 1, 1976, s. 100, 102 107. ENO, Robert B.: The Work of Optatus as a Turning Point in the African Ecclesiology. In: The Thomist: A Speculative Quarterly Review, tom. 37, vol. 4, 1973, s. 669 - 670.

42 TERTULIÁN: De praescriptione haereticorum (d'alej De praes.) 36, 1 - 4. Podl'a: SCHATZ, K.: Dějiny papežského primátu, s. 17.

${ }^{43}$ SCHATZ, K.: Dějiny papežského primátu, s. 10. K otázke vzt’ahu medzi mestom Rímom ako hlavným mestom ríše a postavením rímskeho biskupa pozri HASTINGS, Adrian: The papacy and Rome's civil greatness. In: The Downside Review, tom. 75, vol. 242, 1957, s. 359 - 382. Postavenie rímskej cirkvi a jej biskupa sa odvíjalo v období pred Milánskym ediktom úplne
} 
a Pavlovej mučeníckej smrti a ich trvalej „prítomnosti“ v meste vd’aka ich ostatkom, samozrejme, nevyplývali konkrétne nároky na primát rímskeho biskupa.

Citovaný úryvok odhal'uje aj sebapoňatie cirkvi ako communio ${ }^{44}$ - rovnost' cirkví, ked'že aj cirkvi zakladané vd'aka misionárom z apoštolských cirkví sú apoštolské vd’aka consanguinitas doctrinae (De praes. 32, 6), ${ }^{45}$ pričom apoštolské majú vzhl'adom na svoj pôvod väčšiu váhu a aj autoritu. Predsa však sa nesmierna úcta, ktorej sa títo apoštoli a pamiatka ich mučeníctva tešili, ako aj autorita ich učenia, prenášala na celú rímsku cirkev, akoby ona a oni boli natrvalo jedným nedelitel'ným celkom. ${ }^{46}$ Žiadna iná cirkev s apoštolským pôvodom, ani Antiochia, kde Peter aj Pavol určite pôsobili, či Korintt ${ }^{47}$ sa podobnej úcte netešili. Nešlo však o úctu spojenú s konkrétnymi jurisdikčnými nárokmi.

nezávisle od postavenia mesta Ríma ako centra ríše. Dá sa dokonca tvrdit', že prvé vzniklo napriek odporu k druhému. Autor štúdie sa zaoberal aj postavením rímskej cirkvi za a po Konštantínovi, pričom, hoci štát už zasahoval do cirkevného diania, stále sa nedá hovorit' o odvodzovaní autority (rímskych) biskupov od autority štátu. K poslednej téme aj MORRISON, Karl F.: Rome and the City of God : An Essay on the Constitutional Relationship of Empire and Church in the Fourth Century. In: Transactions of the American Philosophical Society, tom. 54, vol. 1, 1964, s. 3 - 55 .

${ }^{44}$ Ku bližšiemu opisu termínu communio a jeho prejavovaniu sa v praxi pozri REHORČÍKOVÁ, T.: Zdôvodnenie primátu, 2020 s. 13 - 19.

${ }^{45}$ ENO, R. B.: Ecclesia docens, s. 105 - 106. Taktiež: „Omne genus ad originem suam censeatur necesse est. Itaque tot ac tantae ecclesiae una est illa ab apostolis prima, ex qua omnes. Sic omnes primae et omnes apostolicae, dum una omnes probant unitatem : communicatio pacis et appellatio fraternitatis et contesseratio hospitalitatis. " [ = Je nevyhnutné, aby každý druh bol posudzovaný podl'a svojho počiatku. Preto vel'ké množstvo aj vel'kých cirkví je vlastne jednou cirkvou, a to pôvodnou apoštolskou, z ktorej všetky vzišli. A tak každá jedna je apoštolská dovtedy, kým dokazujú jednotu: vzájomným prejavovaním pokoja, nazývaním sa bratmi a výmenou pohostinnosti.] TERTULIÁN: De praescriptione haereticorum. H. HEMMER - P. LEJAY (eds.). Paris : LIBRAIRIE ALPHONSE PICARD ET FILS, 1907, s. 40, 42. De praes. 20, 7 - 8. Dostupné online: https://archive.org/details/depraescriptione00tert/ page/n13/mode/2up. [cit. 1. 2. 2021]. Latinské contesseratio: uzavretie priatel'stva na základe výmeny tesserae. Pravdepodobne ide o zmienku o používaní listov pokoja („cestovných pasoch“), ktoré krest'ania nazývali (aj) tesserae, čo by preklad mohol zastriet'. Tessarae (všeobecne, nielen u krest'anov) boli o. i. symboly či známky, aké si dávali spriatelené rodiny, pôvodne polovice dreva, ktorých zhoda slúžila ako dôkaz. Kto sa nimi preukázal, mal právo na pohostinnost'.

46 SCHATZ, K.: Dějiny papežského primátu, s. 10.

${ }^{47}$ Dionýz z Korintu v jeho liste do Ríma tvrdí, že aj Peter učil v Korinte (cca 166 - 174): „Týmto spôsobom si svojím pôsobivým napomenutím spojil všetko, čo vyrástlo zo semena, ktoré zasial Peter a Pavol rovnako v Rimanoch a Korint'anoch. Pretože obaja siali v našom Korinte a spoločne nás učili: $v$ Itálii tiež učili spoločne v rovnakom meste a boli umučenív rovnakom čase. "EUSEBIUS: The History of the Church, s. 63. HE, 2, 25, 8. 